\title{
Miranda
}

Revue pluridisciplinaire du monde anglophone /

Multidisciplinary peer-reviewed journal on the English-

speaking world

17 | 2018

Paysages et héritages de David Bowie

\section{Katherine Astbury, Mark Philp (eds.), Napoleon's Hundred Days and the Politics of Legitimacy}

\section{Rachel Rogers}

URL: http://journals.openedition.org/miranda/15379

DOI: $10.4000 /$ miranda. 15379

ISSN: 2108-6559

\section{Publisher}

Université Toulouse - Jean Jaurès

\section{Electronic reference}

Rachel Rogers, "Katherine Astbury, Mark Philp (eds.), Napoleon's Hundred Days and the Politics of Legitimacy", Miranda [Online], 17| 2018, Online since 02 October 2018, connection on 16 February 2021. URL: http://journals.openedition.org/miranda/15379; DOI: https://doi.org/10.4000/miranda. 15379

This text was automatically generated on 16 February 2021

\section{(c) $(1)$}

Miranda is licensed under a Creative Commons Attribution-NonCommercial-NoDerivatives 4.0 International License. 


\title{
Katherine Astbury, Mark Philp (eds.), Napoleon's Hundred Days and the Politics of Legitimacy
}

\author{
Rachel Rogers
}

\section{REFERENCES}

Katherine Astbury, Mark Philp (eds.), Napoleon's Hundred Days and the Politics of

Legitimacy (Basingstoke: Palgrave Macmillan, 2018) 288 p, eBook ISBN

978-3-319-70208-7 Hardcover ISBN 978-3-319-70207-0

1 This collection of essays is part of a series coordinated by Palgrave Macmillan under the title War, Culture and Society 1750-1850. It is the culmination of research jointly conducted by the European History Research Centre and the AHRC-funded project "French Theatre in the Napoleonic Era" at Warwick University, and tackles the understudied period lasting from Napoleon's flight from confinement on the island of Elba after his first abdication in April 1814 to his defeat at the battle of Waterloo and second abdication, a period known in retrospect as the Hundred Days. This brief recovery of power was predicated on the deposed Emperor's embracing of the rhetoric and political tools of populism, his seeking of support from former opponents of his autocratic regime (Benjamin Constant most notably) and his promise to bring in liberal reforms. It was also founded on his mobilisation of the potent memory and symbols of the French Revolution. Yet ultimately the recovery foundered, dramatically played out at the battle of Waterloo which signalled Napoleon's final downfall and led to his exile on St Helena. The editors suggest that the predominant legacy of the brief revival of Napoleonic rule was that, in its wake, no subsequent regime could achieve legitimacy without some form of popular consent. The wider project included theatrical and musical performances, a curated online exhibition of material objects and two interdisciplinary conferences. The collection itself, made up of twelve essays, successfully blends work from a wide spectrum of academic disciplines and brings 
together scholars from a diverse set of institutions (Italian, Canadian, Dutch and British universities are represented here) to tackle the interplay of politics and culture in the construction of reactions to Napoleon's reclaiming of power. A number of the essays in part two also deal with the attempts by local elites and new regimes in geographical areas formerly under French imperial rule to assert their own claim to legitimacy during the ongoing diplomatic wrangling between the Allied Powers at the Congress of Vienna. These negotiations continued in parallel and were inseparable from the challenge to the reassertion of the old order across Europe that Napoleon represented.

2 The broad approach to the question of "legitimation" is one of the strengths of the book. Indeed, the essays address how different cultural media (print, song, dance, theatre are discussed here) "inflect the public sphere, shape the debate about legitimacy, and influence the calculations made by those in the political scene" (13). One of the most convincing points made by this collective volume-and echoed in the broader work of its contributors and other scholars- is that politics and culture are inseparable, and any study of political history must devote attention to how "opinion"vital for a leader not relying on coercion to have on side-is shaped by cultural instruments. In the main, the central thread of the book-the media and "history of legitimation" (13)-is scrupulously respected by the authors and the theoretical framework of the collection bears the hallmark of both editors. Mark Philp's previous work on the "inchoate"-a term used by Philp elsewhere- nature of idea formation is in evidence in the insistence on people not harbouring "pre-determined" interests but constructing their reactions "in engagement with wider ideas and cultural values" (19), while Katherine Astbury's resolve to bring to light the social, political and cultural context of dramatic texts and theatre performance informs the broader premise of the essays. The emphasis on bringing to the fore the broader European perspective on events formerly seen through a narrower gaze, is also salutary and chimes with another volume on the same time period, edited by Philp and entitled Re-imagining Democracy in the Age of Revolutions: America, France, Britain, Ireland 1750-1850. The latter charts attitudes to the notion of democracy from different European and North American angles and takes the multidisciplinary approach advocated and practised in this volume. Continuity is also to be seen in the interest taken in judging how Napoleon was "imagined" rather than how he acted.

3 It is also an endorsement of a strain of historical enquiry which seeks to address the significance of short time frames and exceptional events which disrupt smooth continuities but which can sometimes be overlooked in the long historical enquiry. Roger Wells' study on underground revolutionary movements in Britain during the counter-revolutionary and Napoleonic wars (Insurrection: The British Experience 1795-1803) comes to mind, as does Colin Jones' ongoing investigation of popular attitudes to the overthrow of the revolutionary government on the journée of 9 Thermidor. Enquiry into short-lived historical events can disrupt what Michel Foucault saw in L'archéologie du savoir as the obsession of history with continuities and its erasure of instabilities, the "bursting forth" ("l'irruption") of events, as he put it. And sensitivity is indeed shown in many of the essays to the unsettling effect of Napoleon's ultimately brief resurgence. A case in point is Susan Valladares' argument that the melodrama of stage productions during the Hundred Days eased audiences through the "uncertainty" of the time. Equally, John Moores' final essay sees the ambiguities in George Cruikshank's caricature of the return of Napoleon from Elba as part of a shared process 
of figuring out how to respond to the news and part of an ongoing commentary on events.

4 The volume is divided into three clear sections. The essays in the first part address reactions within France to Napoleon's return and tackle the question of whether and how Napoleon secured popular and elite backing as he crossed France and took up the reins of authority in Paris. Michael Sibalis highlights the revival of the revolutionary spirit that Napoleon capitalised on and his ability to mobilise popular enthusiasm within a Parisian population which had not been his chief supporters. In doing so, the author nuances the common portrait of popular acquiescence in the Bourbon restoration and draws attention to the somewhat "staged" (31) re-enactment of revolutionary energy that characterised the Hundred Days. In the essay that follows, John Dunne surveys the state of the historiography of the Hundred Days and roots the foundations of historical thinking on the period in the work of Henry Houssaye and Emile Le Gallo whose respective research was coloured by their "intense patriotism" (44). Such readings thus tended to emphasise the fervour of popular Bonapartism. Without offering firm conclusions of his own, Dunne warns against over-correcting these former portraits and thus overstating the lack of popular support drummed up by Napoleon after the "flight of the eagle" and his resumption of power. Dunne also denies the possibility of synthesis, asserting the need to hear the voices of ordinary people more clearly outside formal politics and suggesting avenues of further investigation. It is a deft article, which warns against firm conclusions in an area where grounds for establishment views on Napoleon's legitimacy in the period remain, in the author's view, "seriously inadequate".

5 Alessandra Aloisi's essay which concludes the first section takes as its subject the trauma of Napoleon's return for those who had supported the Bourbon monarchy. Aloisi studies one individual's reaction, through the lens of Maine de Biran's diary, electing to highlight the interplay between philosophical and political perspectives. She brings to the fore Biran's interweaving of his own physical and psychological ills with what was taking place on the political stage. The article is a counterpoint to the two previous articles, both in method and subject, reflecting the multidisciplinary objective of the volume. While the reader could be forgiven for seeing a certainperhaps intentional-disconnectedness between this study and the preceding ones, and perhaps some side-stepping of the notion of legitimacy in the body of the essay, a number of the insights, notably on the "grammar of melancholy", as well as the decision to provide an intimate psychological portrait of an opponent of Napoleon's return are helpful in furthering our understanding of the complexity of reactions to Napoleon's sudden resurgence.

6 Each of the essays in the second part, succinctly titled "Legitimacy Beyond France," furthers readers' awareness of the impact of Napoleonic conflict on former imperial territories and broaches the topic of how recently established regimes negotiated their legitimacy once Napoleon returned to the fray. What is occasionally more difficult to glean from these portraits-understandably, given that the subject in this section is countries no longer under direct threat of invasion-is the singularity of the period in the overall construction of reactions to the Napoleonic era. At times Napoleon's brief return appears to be subsumed into a broader narrative of national reawakening and Napoleonic despotism. Leighton S. James' essay explicitly identifies the Hundred Days as "a microcosm of attitudes and behaviours that had been evident during the previous 
decade of warfare" (84). It is a subtle and instructive account of the place of Napoleon's brief return in the overall construction of German nationalism and the different sentiments felt within public opinion at the time, ranging from renewed patriotic fervour to war weariness and disenchantment with the negotiations at Vienna. The article sheds light on how the return of Napoleon "tested new loyalties" in those areas previously under imperial control and with enduring pockets of "popular attachment" (95) to Napoleon-notably in the Rhineland. In the author's insistence on the Hundred Days being "another campaign in a long series of conflicts" the reader is led to wonder whether the impact of the Hundred Days was felt as acutely in former imperial lands as in France itself.

7 This is an issue expertly dealt with by Valentina Dal Cin in her essay on the reactions of Venice's local elites to the news and rumours surrounding the Hundred Days. Venice had been incorporated into the Napoleonic Kingdom of Italy from 1806 to 1814 and in 1809 the Austrian army had challenged but not overcome Napoleonic rule. Dal Cin argues that the Hundred Days reignited the memory of 1809 and thus local leaders were reluctant to take a stance either in support of Hapsburg claims or in favour of Napoleon until some certainty had been reached at the table in Vienna. In her study of the private letters of members of the Venetian elite, (primarily those siding with the Austrians), Dal Cin found that there was a tendency to accept false reports of Napoleon's capture or lack of popular legitimacy since this "spoke to the group's wishful thinking" (110). In the essay that follows, Lotte Jensen adds to this discussion on the impact of Napoleon's return on nation-building in former French territorial possessions, and highlights the case of the Netherlands, which had been under French occupation from 1806 to 1813. In particular Jensen examines the impact of the Hundred Days on William I's attempts to consolidate his position as sovereign king of the United Kingdom of the Netherlands and secure the political union between the Dutch and Belgium ratified in the Eight Articles of London. Jensen suggests that William benefited from Napoleon's escape in that he could use the political uncertainty generated by the events to engender unity between the North and the South, often through the nostalgic recalling of a mythical past. What is striking in the articles in this section of the book is the extent to which the Hundred Days can be seen as part of a long process in the withdrawal and defeat of imperial France.

In introducing readers to the dynamics within emerging regimes in former imperial territories the contributors to this second section broaden the scope of our understanding of the aftermath of Napoleonic rule while underscoring perhaps the broad lack of enthusiasm-within local elites at least-for a return to French rule within war weary communities where revolutionary rhetoric was less potent. Martina Piperno highlights the trajectory of Joaquim Murat, King of Naples, who had been a fervent supporter of Napoleon before switching sides and courting the Austrians in 1814. She shows how he lent his support to Napoleon during the Hundred Days while positing himself as a defender of Italian freedom, despite still reassuring England and Austria of his loyalty. Murat would go on to carve out a reputation for himself as a defender of Italian independence and an instigator of the Italian Risorgimento, yet Piperno persuasively argues that this reading is a retrospective re-appropriation of Murat, told to fit a certain "teleological narrative" (156). Murat, in his time, was derided in contemporary satire. The concluding essay is in many ways a stand-alone study. It charts the hope provided by Napoleon's return for the British abolitionist movement which, in the months before the Hundred Days, had unsuccessfully attempted to press 
home its agenda at the Vienna congress. Alan Forrest's point here is that the Hundred Days gave a new impetus to the flagging campaign, led by Wilberforce and Clarkson, to see the slave trade abolished in the countries involved in the peace negotiations. The negotiators had failed to back abolition until that point, but when Napoleon returned to Paris he issued a decree abolishing the slave trade. As Forrest acknowledges, this was part of reinventing himself as a man of the people and an expedient decision rather than one of principle. Even after Waterloo and Napoleon's final abdication, abolition was retained as a clause in the Vienna compact, yet Forrest meticulously traces its ineffectual application and the widespread transgressions in the years following 1815.

"Cultural artefacts, events and performances are not an effect of this process, but to a significant extent the site of it, thus providing diverse media through which legitimacy comes to be tried, tested, subverted, reshaped and repudiated." (14). The editors articulate the crucial interplay of culture and politics from the outset, and part three of the volume bears out this opening position with a fascinating set of essays which emphasise cultural manifestations as "sites" rather than "effects" of the process of seeking and securing political legitimacy. Susan Valladares shows how the patent theatres of Covent Garden and Drury Lane were not only stages where performances could be infused with the political debates exercising the nation but could also be vectors of news and ideas. Valladares suggests that there were few direct references to Waterloo in contemporary stage productions, but that there were means by which the stage allowed audiences to consider national politics, either through the style of specific actors, or through the use of dramatic forms less subject to censorship, such as pantomime. The author shows how actor Edmund Kean, like Napoleon, was perceived as a man of the people. His abilities on stage-sudden and dramatic transitions, reappearances and returning to life after death-appeared to mimic those of Napoleon in his "refusal to relinquish authority and quit the political stage" (198). Yet Valladares is careful not to suggest that there was one sole interpretation of performances, arguing that the same scene could be read in different ways, either as a vindication or a rejection of Napoleon. In the uncertainty of the Hundred Days, parallels could be drawn between the melodramatic style of actors such as Kean, and the equally dramatic resurgence of Napoleon, thus helping audiences to work through the instability of the times.

Erica Buurman and Oskar Cox Jensen combine their respective knowledge and practice to put forward some fascinating insights into the role of commemorative dance music at the close of the Napoleonic wars. By comparing popular songs and social dance listings, they are able to draw conclusions as to the role of such media in bolstering patriotic fervour during wartime. Although they reject the idea that dance is not "political", the authors suggest that while popular song, by virtue of the lyrics and rhetorical function, could offer partial commentary on national events, commemorative dances could appear more neutral and less explicitly patriotic, particularly as distance opened up between the events and the publication of collections. Not only did they have an "added element of collective participation" (219)-giving them a central role in moments of celebration-but they could be a more detached commentary on the past. Social dance could not express complex political sentiments and therefore had an element of inclusiveness which lent itself to the purpose of collective celebration, preserving the memory of an event without engaging with it critically. The authors suggest that non-discursive and bodily practices such as 
social dance can be an effective medium for "capturing the longer-term societal memory of an event" (228).

The final two essays in this section deal with journalistic and satirical reactions to the Hundred Days. Mary-Ann Constantine studies the reporting by the Welsh-language newspaper Seren Gomer during the period. Constantine notes that the newspaper was often apt to comment on the uncertain nature of information and acknowledged the blend of rumour and news that reached the paper. For the author, the Hundred Days revealed "a set of intensely concentrated possibilities" (239), reaffirming once again-as in Jensen's essay-the difficulty encountered by outside commentators in taking a firm position on Napoleon's progress. This was perhaps indicative of the complex and shifting responses to Napoleon within Britain. The final essay in the collection is devoted to the representation of Napoleon in George Cruikshank's satirical caricature. It is a fitting article to conclude the volume since the author John Moores, in his discussion of Cruikshank's "Escape of Buonoparte from Elba", brings to light the ambivalent response of the caricature artist to Napoleon's return. Cruikshank followed his mentor James Gillray in his "penchant for ambiguous, subversive, and roguish messages" which could undercut clear-cut positions. Cruickshank, even if his illustrated work was set side-by-side with loyalist texts, could undercut the legitimacy of the ruling powers in both Britain and France.

This is an enlightening and well-documented set of essays which illuminate in fascinating detail and breadth a period of history that has received comparatively little attention in the overall picture of Napoleonic rule. The decision to focus on "legitimation" allows the authors to move away from an onus on military conflict to address cultural and political reactions to the Hundred Days from a broader European perspective. For scholars of the French revolution and Napoleonic era, as well as those seeking to expand their understanding of the context to the Congress of Vienna, it is a precious resource. Many of the essays will also appeal to those working in the field of cultural history or attempting to open up new avenues in the way politics is dealt with in historical enquiry.

\section{INDEX}

Keywords: legitimacy, cultural media, popular consent, Waterloo, Hundred Days, French Revolution, Congress of Vienna, Allied Powers, caricature

Mots-clés: légitimité, médias culturels, consentement populaire, Waterloo, Cent-Jours, Révolution française, congrès de Vienne, forces alliées, caricature 
AUTHORS

RACHEL ROGERS

Maître de Conférences

Université Toulouse Jean Jaurès

rogers@univ-tlse2.fr 